\title{
MATHEMATICAL LITERACY ABILITY AND METACOGNITIVE CHARACTERISTICS OF MATHEMATICS PRE-SERVICE TEACHER
}

\author{
Christina M. Laamena*, Theresia Laurens \\ Universitas Pattimura, Indonesia
}

\begin{tabular}{l} 
Article Info \\
\hline Article history: \\
Received Oct 1, 2020 \\
Revised Feb 14, 2021 \\
Accepted July 4, 2021 \\
\hline
\end{tabular}

\section{Keywords:}

Mathematical literacy, Metacognition

\begin{abstract}
This study aims to determine the characteristics of students' metacognition in solving mathematical literacy problems. The metacognitive traits explored are related to awareness in planning, monitoring, and evaluating the design of the thinking process used. The research method used is a mixed-method (sequential explanatory), which uses quantitative research results to conduct qualitative research. The research subjects were 80 early semester students who took the literacy test and chose six respondents representing the upper, middle, and lower groups, with two people in each group to be interviewed. The results showed that the mathematical literacy skills of pre-service teachers were at a low level. Metacognitive characteristics that appear in the low group are (1) realizing that the solution of strategy is not right but not improved; (2) planning to develop a settlement strategy, but are not sure, (3) do not carry out the re-check process, and (4) do not believe what is being thought and do not understand the concept. Metacognitive traits in the middle group are (1) aware of what they are thinking, (2) consciously plan various strategies to improve thinking accuracy, but do not always use these strategies, (3) tend to monitor the thinking process, and (4) show tendency to master the basic mathematical concepts of the problems at hand. The characteristics of metacognition in the high group during problem-solving are (1) Using various strategies to demonstrate or improve the accuracy of thinking (sketching, drawing), (2) Analyzing the problem before solving it, and (3) Understanding and mastering the mathematical concepts that underlie the problem which is given.
\end{abstract}

Copyright $(2021$ IKIP Siliwangi. All rights reserved.

\section{Corresponding Author:}

Christina M. Laamena,

Department of Mathematics Education,

Universitas Pattimura

Jl. Ir. M. Putuhena, Poka, Tlk. Ambon, Maluku 97233, Indonesia

Email: christinmath18@gmail.com

\section{How to Cite:}

Laamena, C. M., \& Laurens, T. (2021). Mathematical literacy ability and metacognitive characteristics of mathematics pre-service teacher. Infinity, 10(2), 259-270.

\section{INTRODUCTION}

Mathematics has an important role in life, but in practice some students still consider mathematics to be a difficult subject (Angateeah, 2017; Khiat, 2010; Laurens, 2010; Sholihah \& Afriansyah, 2017). This is because mathematics is always introduced as an abstract discipline without relating it to everyday realities (Fitriani et al., 2018; Kadarisma et al., 2020; Kariadinata, 2021; Novriani \& Surya, 2017). In addition, students are also less 
taught with mathematical skills, as a result they are not skilled at solving problems even according to Tambychik and Meerah (2010) and Heong (2005) there are phases in problem solving that are not implemented properly.

Problems in mathematics are interpreted differently by the individuals who face them. According to Schoenfeld (1987), mathematics problems for students are tasks that: (1) attract students' attention and challenge them to solve them, (2) it is not easy to find solutions. The problem as a situation that requires resolution and for which the individual sees no apparent or obvious means or path to obtaining the solution. There are problems that challenge a person but not others (Laurens, 2010).

In learning mathematics students need to be introduced to the problem and how to solve it. Problems presented to students need to be studied for their relationship with the reality they are facing, meaning that these problems must be contextual problems that have been experienced by students. Mathematical problems that are far from the reach of students will give the impression that mathematics only fills the curriculum without being useful in everyday life. Therefore, the mathematical concept introduced must be related to its use in everyday life (Basibas, 2020; Reyes et al., 2019; Root et al., 2020; Yee \& Bostic, 2014). The ability to apply mathematical concepts in everyday reality is known as mathematical literacy.

Stacey (2011) state that the concept of literacy is closely related to several other concepts discussed in mathematics education, but the most important is modeling (mathematical modeling) which is called the process of mathematics. According to de Lange (2003), the mathematical process begins with problems in real life, then the problem solver tries to identify relevant mathematical information, and reorganizes the problem according to the identified mathematical concepts, followed by gradually reducing real situations, the third step takes from real world problems to mathematical problems, and the fourth step is interpreting mathematical solutions in the real world. Mathematical literacy is the application of mathematical knowledge, methods and processes in a variety of contexts. Mathematical literacy contains more than the use of basic knowledge and procedures that enable individuals to have it.

de Lange (2003) explains that mathematical literacy is related to (1) numerical literacy which consists of material related to quantity (Quantity), (2) quantitative literacy which consists of the form of relationships and changes (change and Relationship) and uncertainty (uncertainty) and (3) spatial literacy which consists of form and space (Space and Shape). Numerical Literacy is concerned with the ability to use numerical data to evaluate statements relating to problems and situations that require mental processing and estimation of real-world context. Quantitative literacy developing numbers includes the use of mathematics as it relates to change, quantitative relationships and uncertainty. Spatial literacy emphasizes the ability of individuals in the context of three dimensions that are encountered in their daily lives. This requires an understanding of the properties of objects, the relative positions of objects and a visual perception of the object's dimensions.

There is a level of mathematical literacy suggested by Bybee (2008). This level is based on reading literacy skills, namely: (1) the lowest level called illiteracy which means the inability to deal with information that is considered relevant, namely ignorance of the basic concepts and methods of mathematics, (2) the second level is nominal literacy, namely literacy that is limited to understanding term or name. In this case the individual understands mathematical terms, questions or topics as part of mathematics, but is minimal in comparing these understandings, (3) the third level is functional literacy, which is the level where a person can use the knowledge gained in the activities required. In this case the standard method of mathematics can be applied to solve simple problems, (4) the fourth level is the conceptual and procedural literacy level. This dimension consists of developing an understanding of interrelated concepts. Procedural knowledge leads to a mathematical 
discovery process, in which individuals understand and use mathematical concepts in the context of mathematical investigations. Conceptual and procedural literacy contains some understanding of the structure and central function of mathematical ideas such as optimization and recognition patterns, (5) the highest level is the multidimensional literacy level. This level includes the conceptual understanding of mathematics and the social dimensions of mathematics. Individuals may develop some understanding and connections in mathematics, and other knowledge content. Its main focus is to apply mathematics functionally in order to solve problems and modeling as well as the transition process from the real world to mathematics and vice versa.

Based on the understanding of literacy, in the teaching and learning process, students need to be given an understanding of the benefits of studying mathematics, so that they feel that mathematics is not a scary subject but a subject that forms a mindset in analyzing problems faced in everyday life and finding solutions. Students need to be faced with context problems that force them to find solutions by utilizing mathematical concepts and procedures that are learned. The use of mathematical concepts and procedures requires simple to complex levels of thought. According to Charles and Lester (1984) there are 3 aspects that influence solving mathematical problems, namely (1) cognitive aspects, including conceptual knowledge, understanding and strategies for applying this knowledge; (2) affective aspects, which are aspects that affect the tendency of students to solve problems; and (3) metacognition aspects, including the ability to organize one's own thoughts.

Metacognition aspects are important because they relate to one's awareness of the processes and results of thinking. Metacognition is defined variously by experts, but in general the notion of metacognition is related to the awareness, knowledge and control that a person exerts over his own thinking processes and results. According to Yong and Kiong (2005), "Metacognition refers to one's knowledge concerning one's own cognitive processes and products or anything related to them. Metacognition refers, among other things, to the active monitoring and consequent regulation and orchestration of these processes in relation to the cognitive objects or data on which they bear, usually in the service of some concrete goal".

Flavell (2004) defines the first aspect of metacognition as one's knowledge of cognitive processes and results or everything related to it, then the second aspect of metacognition is defined as monitoring and self-regulation of one's own cognitive activities. The same understanding was put forward by Garofalo and Lester (1985) that to describe a person's knowledge and control over his mental processes, including knowledge about himself, his tasks, and the strategies used. For example, a student can find out his ability to solve problems well if he takes the time to check the results of his work, especially if he uses diagrams as one of his strategies. Schoenfeld (2016) defines metacognition as follows: "metacognition is thinking about our thinking and it comprises of the following three important aspects: knowledge about our own thought processes, control or self-regulation, and belief and intuition (that is, metacognition is thinking about our own thinking which consists of three important aspects, namely: knowledge of our own thought processes, selfcontrol or self-regulation, and belief and intuition). Metacognition is the knowledge, awareness, and control of our cognitive processes. Metacognition is very important because our knowledge of cognitive processes can help to organize and choose strategies for solving problems that are being experienced (Akben, 2020; Desoete \& De Craene, 2019; Lingel, Lenhart, \& Schneider, 2019; Yong, Gates, \& Chan, 2019).

In relation to literacy, Israel et al. (2006) state that metacognitive skills should be taught within the context of authentic literacy engagement, and students should be given sufficient practice in their application that they know, when, why, and how to use them relatively effortlessly. In this study, the metacognition activities that were considered were 
(1) How students recognized and identified problems and defined the elements of the situation presented; (2) How do students represent the problem and make connections between the information found; (3) How to plan and decide steps for completion and determine how to achieve these goals; (4) How to check / monitor the results it has obtained; (5) how to evaluate the results and solutions made.

The low ability of mathematical literacy is due to the fact that Indonesian students are not used to solving problems with the types of PISA and TIMSS questions (Ekawati, Susanti, \& Chen, 2020; Sulistiyarini, 2021) and metacognition that do not run smoothly. Therefore, prospective teachers are the first to have their metacognition improved so that they can help their students in the future. In addition, the characteristics of metacognition based on the level of mathematical literacy have not been carried out, so this study will help educators to encourage the emergence of students' metacognition according to their literacy level. Thus, the purpose of this study is to describe the mathematical literacy skills of mathematics pre-service teachers and to analyze the metacognitive characteristics used in mathematical literacy. Metacognition characteristic analysis was based on the grouping of students (upper group, middle group and lower group).

\section{METHOD}

The research method used is a mixed method, which uses the results of quantitative research to conduct qualitative research. Data from the test results were used as the basis for conducting interviews and document analysis to determine metacognition activities from data sources consisting of 80 students and 6 students were selected to be interviewed and become research subjects.

Quantitative data in the form of test scores were analyzed using descriptive statistics by calculating the mean value of literacy skills and the percentage of level grouping at each literacy ability level. The research instrument used was a literacy ability test which consisted of 5 questions, namely 1 social mathematics question, 2 work questions, 2 geometric questions as well as interview guidelines and an assessment rubric. Interviewed subjects consisted of 6 people representing each group. The analysis of metacognition characteristics that appears is based on the analysis of the test results document and the analysis of the results of the interviews with the data analysis technique used, namely reducing data, presenting data and concluding the results.

\section{RESULTS AND DISCUSSION}

\subsection{Results}

There are 2 types of research data that will be discussed, namely literacy ability test results which are quantitative data and work analysis data and interview transcripts which are qualitative data. The test result data for 3 classes shows that the mean value obtained is class $A=30.8$, class $B=27.6$ and class $C=22.2$. This shows that there are differences in the results of literacy skills tests between subjects in the three groups. Based on the results of the test, grouping was carried out in the upper, middle and lower groups in order to obtain the percentage of the upper group (high category) as much as 19\%, the middle group (medium category) 60\% and the lower group (low category) 21\%. Furthermore, based on the results of this work and based on the indicator of literacy levels put forward by Bybee (2008), then the literacy level is analyzed with the results can be seen in Table 1. 
Table 1. Data of Literacy level (Bybee, 2008)

\begin{tabular}{clccccc}
\hline \multirow{2}{*}{ No } & \multirow{2}{*}{ Level of Literacy } & \multicolumn{5}{c}{ Number } \\
\cline { 3 - 7 } & & $\mathbf{1}$ & $\mathbf{2}$ & $\mathbf{3}$ & $\mathbf{4}$ & $\mathbf{5}$ \\
\hline 1. & Illiteracy & $21.30 \%$ & $12.50 \%$ & $13.80 \%$ & $17.50 \%$ & $10.00 \%$ \\
2. & Nominal Literacy & $37.50 \%$ & $12.50 \%$ & $13.80 \%$ & $23.50 \%$ & $20.00 \%$ \\
3. & Functional Literacy & $12.50 \%$ & $16.25 \%$ & $28.60 \%$ & $28.80 \%$ & $13.80 \%$ \\
4. & Conseptual \& Procedural Literacy & $20.00 \%$ & $7.50 \%$ & $11.30 \%$ & $11.30 \%$ & $8.80 \%$ \\
5. & Multidimensional Literacy & $0.00 \%$ & $0.00 \%$ & $0.00 \%$ & $0.00 \%$ & $0.00 \%$ \\
\hline
\end{tabular}

Based on the analysis of the document results, it is known that not all subjects worked on the questions given. Subjects who did not do question number 1 were $10 \%$, question number 2 was $10 \%$, question number 3 was $11.3 \%$, question number 4 was $25 \%$ and question number 5 was $48.5 \%$.

Table 1 shows that the level of literacy of mathematics pre-service teachers on all question numbers does not reach 50\%, even if no one is at the multidimensional literacy level. Persetance illteracy which only reaches $20 \%$ indicates that $80 \%$ of mathematics preservice teachers are able to identify information that is considered relevant or already know the basic concepts and mathematical methods that must be used to solve problems. The level of conceptual literacy and procedural literacy only reaches $20 \%$ and none of the mathematics pre-service teachers have the ability at the multidimensional literacy level.

Based on the analysis of worksheets documents (see Figure 1), it can be seen that there are indications of the use of metacognition, for example the results of work that are crossed out, deleted then replaced, represent problems visually indicating the use of metacognitive knowledge, especially on the strategy variable.
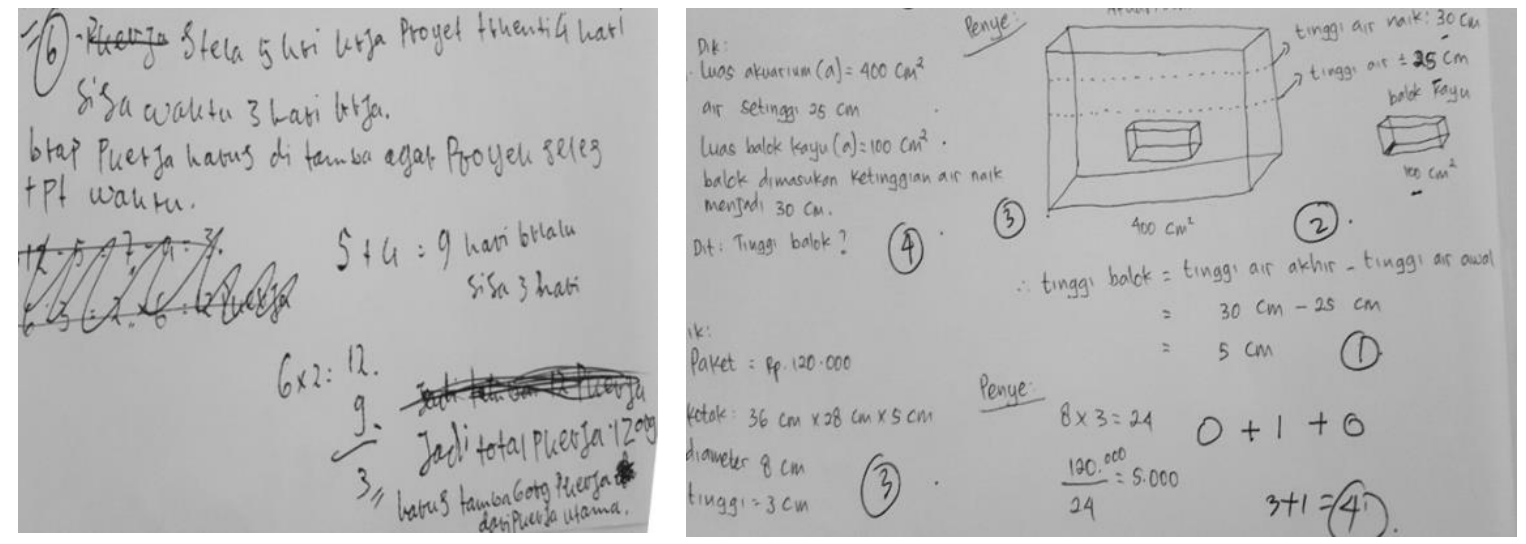

Figure 1. Example of students' work

Based on the work done by the students (see Figure 1), six people were selected as respondents to be interviewed. Each of a number of two people representing the high, low and medium groups. Interviews were conducted to reveal metacognitive characteristics in mathematical literacy. The following is an excerpt of an interview from one of the subjects.

$\mathrm{R}$ : Pay attention to the first problem. After reading this issue what do you think

$\mathrm{S} 1$ : how to get the answer

$\mathrm{R}$ : Apart from that, is there anything else?

$\mathrm{S}$ : Remember fractions 
$\mathrm{R}$ : why fractions?

$\mathrm{S}$ : Because what is written (pointing to the results of his work) is one-half, one-third

$\mathrm{R}$ : What does this matter tell

$\mathrm{S} 1$ : Distribution of money

$\mathrm{R}$ : Did your reading time know what to want in this matter

S1 : How much money did Dony collect

$\mathrm{R}$ : The answer?

S1 : Pointing at the answer with a smile to answer 437, (slowly said "it seems wrong")

$\mathrm{R} \quad$ : So why was it crossed out?

$\mathrm{S} 1$ : First, the number must be equal to 1500, but I'm confused, I think it's not like this, then I crossed it out

The results of the interview indicated that the metacognitive characteristics that emerged were (1) recalling the mathematical symbols contained in the problem which were metacognitive knowledge specifically referred to as metamemory; (2) know the meaning of the question but do not believe the answer is correct. This indicator is included in the metacognitive experience component, especially with regard to cognitive monitoring and evaluation.

Consider the following interview excerpt (subject at the conceptual and procedural literacy level)

$\mathrm{R} \quad$ : Why do you draw like this

$\mathrm{S} 2$ : This only helps me to understand the position of the blocks

$\mathrm{R}:$ What is the position of the blocks

$\mathrm{S} 2$ : There is an incoming beam, you need to know its position

$\mathrm{R}$ : but the solution looks like this (pointing to the block image)

$\mathrm{S} 2$ : because the block is put into the tub,

$\mathrm{R}$ : are you sure the answer is correct?

S2 : Well, because I was asked about volume, I remember the volume of blocks, only because there is 1 block in the water

$\mathrm{R} \quad$ : Do you have other ways besides this

$\mathrm{S} 2: N o$

This interview snippet shows that the subject realizes and then plans strategies that make it easier for him to solve problems. This is included in the metacognition knowledge component, especially individual variables and strategy variables. In relation to the metacognitive experience used, it can be seen that there is monitoring of the cognitive processes that occur by deleting and deleting as well as an evaluation process that raises awareness, for example, lack of confidence in what is done and have no other way than the way that has been made.

\subsection{Discussion}

From the results of the analysis of the mathematics teacher candidate literacy level, it can be seen that from the 5 questions given 3 questions related to the quantity content, 2 questions related to the content of space and shape. Quantity content is concerned with understanding the relationships and patterns of numbers, including the ability to understand size, number patterns, and everything related to numbers in everyday life, such as counting and measuring certain objects. Included in the content of this quantity is the ability to reason quantitatively, present something in numbers, perform systematic calculations. According to Prince et al. (2021), the ability students need in quantitative literacy is the ability to: (a) 
identify and express relationships in an effective symbolic form, (b) use computational tools to process information, and (c) interpret results this calculation.

Based on the results of the analysis of the level of literacy skills, it can be seen that the average level of literacy skills is still low (because it's less than 30\%). This can be seen from the fact that there are no subjects who occupy a special multidimensional level. There are less than $50 \%$ of subjects at each literacy level and are more dominant in nominal literacy. This shows that their ability is limited to recognizing symbols in the problem, not understanding relevant information and not understanding basic mathematical concepts. This indicates that there is an incomplete understanding of the problem being solved which is known as instrumental understanding. Instrumental understanding is a type of understanding related to the use of methods or rules without knowing (realizing) the reasons for the use. Gough (2004) state that instrumental understanding as rules without reasons.

Percentage of literacy nominal that is higher than other literacy shows that undergraduate students have a higher ability to solve problems using calculations or numbers. Laamena, Nusantara, Irawan, and Muksar (2018) mention that students are able to solve problems involving numbers (inductively) but if they are faced with problems that require deductive reasoning then they will have difficulty. So according to Laamena and Nusantara (2019), if the problem is presented in a statement, students tend to use examples of numbers to test the truth of the statement (Numerical backing).

They understand the questions but are unable to compare what is understood with the relevant mathematical content. For example, the difficulty in applying the different denominated fraction operation concept. In the functional literacy a group they try to use formulas to solve problems but then experience difficulties in the process of solving them, for example the concept of comparison to be used, but in the process they have difficulty equating the two forms of fractions so that they subtract the variables. This shows that knowledge about a procedure does not always guarantee that someone understands the concepts that underlie the material, it really depends on the metacognitive knowledge one has (Akben, 2020; Desoete \& De Craene, 2019; Lingel et al., 2019; Yong et al., 2019).

Uncontrolled metacognitive knowledge can lead to errors, as argued Veenman, van Hout-Wolters, and Afflerbach (2006) that metacognitive knowledge about how we learn can be wrong or right and this knowledge about ourselves (self-knowledge) is likely to change. This change will occur when there is cognitive monitoring activity that raises awareness (Desoete \& De Craene, 2019; Kaune, 2006; Smith \& Mancy, 2018; Stillman \& Mevarech, 2010; Veenman \& van Cleef, 2019).

In the conceptual and procedural literacy groups, they try to link some of the concepts needed, for example problem number 1 (an equation involving fractions), the problem is symbolically represented but then cannot evaluate the results obtained with what is needed in the problem. The interesting thing was that some of these groups tried to represent the problem visually so that it was easier to find answers and match them with what was being asked. One example is how to conduct investigations through pictures to find answers to problems, but the problem faced is a lack of knowledge of other concepts needed, for example the concept of physics about the mass of objects. The interesting thing about one of the subjects is trying to interpret the problem by making a pattern of the relationship between the number of workers and the specified time.

In the multidimensional literacy a group there is an understanding of mathematical concepts, especially spatial structures so that the spatial abilities of the subjects in this group apply mathematical concepts by symbolically representing problems in sketch form. Here they carry out a mathematical process by trying to create a mathematical model (Chao, Liu, \& Yeh, 2018; Muhammad, Kumaidi, \& Mukminan, 2020; Yong et al., 2019; Zhong \& Xia, 2020). 
Based on the results of the analysis of the interviewed subjects and related to their work results, it can be concluded that almost all metacognition components appear in mathematical literacy, especially those related to metacognition knowledge. The component of metacognitive knowledge that emerges leads to awareness of the concepts they possess, for example the awareness that they do not understand the concept of fractional operations, they do not understand how to relate known geometric concepts to other concepts needed in relation to problem solving.

In relation to the level of mathematical literacy, in general the use of metacognition in the illiteracy group and the nominal literacy group is strongly influenced by conceptual knowledge and procedural knowledge. The characteristics of metacognition are realizing that the solution strategy is not right but not improving it, planning the strategy that is made but not realizing the accuracy of the strategy, not showing monitoring activities and not sure what is being thought and tends to not master the concept. For the functional literacy group, the use of metacognition leads to awareness of their knowledge but still has difficulty connecting some related mathematical concepts (Ali et al., 2020; Özenç \& Dikici, 2016; Zhussupova \& Kazbekova, 2016). In the use of metacognition activities, the characteristics that are raised are being aware of what is thinking, planning various strategies consciously to increase the accuracy of his thinking, but not always using these strategies, tending to monitor his thinking processes, showing a tendency to master the mathematical concepts underlying the problem.

For the conceptual and procedural and multidimensional literacy group, the characteristics of metacognition that arise during problem solving are the use of various strategies to demonstrate or improve the accuracy of their thinking (making sketches, drawing), analyzing problems before solving them, understanding and mastering the mathematical concepts underlying the given problem, even though In some steps, it was difficult to check, but due to a lack of conceptual knowledge, the answers given were not correct (Amin \& Mariani, 2017; Bakar \& Ismail, 2020; Kramarski \& Zoldan, 2008; Salam et al., 2020; Schneider \& Artelt, 2010; Su et al., 2016; Zepeda et al., 2019).

\section{CONCLUSION}

This study concludes that the average mathematical literacy ability of pre-service teachers is in the low category and if it is related to Bybee's level (2008), the average is still at the level of nominal illiteracy and literacy, meaning that mastery of mathematical concepts is still low and only limited to introduction. symbols and mastery of mathematical procedures are still lacking. In relation to the use of metacognition, it can be said that those in the low group have difficulties in developing and utilizing their metacognition because of the lack of conceptual knowledge and procedural knowledge of mathematics. Subjects in the high literacy group can take advantage of their metacognition in solving several problems by realizing their knowledge regarding mathematical concepts and strategies used in solving problems including monitoring and evaluating their cognitive processes.

\section{REFERENCES}

Akben, N. (2020). Effects of the problem-posing approach on students' problem solving skills and metacognitive awareness in science education. Research in Science Education, 50(3), 1143-1165. https://doi.org/10.1007/s11165-018-9726-7 
Ali, R., Dossanova, S., Kulambayeva, K., Sadykova, A., \& Tazhibayev, T. (2020). Functional Literacy in the Context of Human Capital Development. Universal Journal of Educational Research, 8(3), 1017-1026. https://doi.org/10.13189/ujer.2020.080336

Amin, I., \& Mariani, S. (2017). PME learning model: The conceptual theoretical study of metacognition learning in mathematics problem solving based on constructivism. International Electronic Journal of Mathematics Education, 12(3), 333-352.

Angateeah, K. S. (2017). An investigation of students' difficulties in solving non-routine word problem at lower secondary. International Journal of Learning and Teaching, 3(1), 46-50. https://doi.org/10.18178/ijlt.3.1.46-50

Bakar, M. A. A., \& Ismail, N. (2020). Mathematical Instructional: A Conceptual of Redesign of Active Learning with Metacognitive Regulation Strategy. International Journal of Instruction, 13(3), 633-648. https://doi.org/10.29333/iji.2020.13343a

Basibas, A. T. (2020). Developing and Contextualizing Instructional Materials in Mathematics for Grade 6 Pupils. Asian Journal of Education and Social Studies, 13(4), 44-53. https://doi.org/10.9734/ajess/2020/v13i430341

Bybee, R. W. (2008). Scientific literacy, environmental issues, and PISA 2006: The 2008 Paul F-Brandwein lecture. Journal of Science Education and Technology, 17(6), 566585. https://doi.org/10.1007/s10956-008-9124-4

Chao, J., Liu, C. H., \& Yeh, Y. H. (2018). Analysis of the learning effectiveness of Atayal culture CPS spatial concept course on indigenous students. Eurasia Journal of Mathematics, Science and Technology Education, 14(6), 2059-2066. https://doi.org/10.29333/ejmste/86162

Charles, R. I., \& Lester, F. K. (1984). An evaluation of a process-oriented instructional program in mathematical problem solving in grades 5 and 7. Journal for Research in Mathematics Education, 15(1), 15-34. https://doi.org/10.5951/jresematheduc.15.1.0015

de Lange, J. (2003). Mathematics for literacy. In B. L. Madison \& L. A. Steen (Ed.). Quantitative literacy: Why numeracy matters for schools and colleges (pp. 75-89). Princeton, NJ: The National Council on Education and the Disciplines.

Desoete, A., \& De Craene, B. (2019). Metacognition and mathematics education: An overview. ZDM, 51(4), 565-575. https://doi.org/10.1007/s11858-019-01060-w

Ekawati, R., Susanti, S., \& Chen, J. C. (2020). Primary students'mathematical literacy: A case study. Infinity Journal, 9(1), 49-58. https://doi.org/10.22460/infinity.v9i1.p4958

Fitriani, N., Suryadi, D., \& Darhim, D. (2018). The students' mathematical abstraction ability through realistic mathematics education with VBA-Microsoft Excel. Infinity Journal, 7(2), 123-132. https://doi.org/10.22460/infinity.v7i2.p123-132

Flavell, J. H. (2004). Theory-of-mind development: Retrospect and prospect. MerrillPalmer Quarterly, 50(3), 274-290.

Garofalo, J., \& Lester, F. K. (1985). Metacognition, cognitive monitoring, and mathematical performance. Journal for research in mathematics education, 16(3), 163-176. https://doi.org/10.5951/jresematheduc.16.3.0163 
Gough, J. (2004). Reflections on Skemp's contributions to mathematical education. Mathematics Education Research Journal, 16(1), 72-77.

Heong, T. L. (2005). Problem solving abilities and strategies in solving multistep mathematical problems among form 2 students. Kertas Projek Sarjana. Kuala Lumpur: Universiti Malaya.

Israel, S. E., Block, C. C., Bauserman, K. L., \& Kinnucan-Welsch, K. (2006). Metacognition in literacy learning: Theory, assessment, instruction, and professional development. London: Lawrence Erlbaum Associates.

Kadarisma, G., Fitriani, N., \& Amelia, R. (2020). Relationship between misconception and mathematical abstraction of geometry at junior high school. Infinity Journal, 9(2), 213-222. https://doi.org/10.22460/infinity.v9i2.p213-222

Kariadinata, R. (2021). Students' reflective abstraction ability on linear algebra problem solving and relationship with prerequisite knowledge. Infinity Journal, 10(1), 1-16. https://doi.org/10.22460/infinity.v10i1.p1-16

Kaune, C. (2006). Reflection and metacognition in mathematics education-tools for the improvement of teaching quality. ZDM, 38(4), 350-360. https://doi.org/10.1007/BF02652795

Khiat, H. (2010). A grounded theory approach: Conceptions of understanding in engineering mathematics learning. The Qualitative Report, 15(6), 1459-1488. https://doi.org/10.46743/2160-3715/2010.1356

Kramarski, B., \& Zoldan, S. (2008). Using errors as springboards for enhancing mathematical reasoning with three metacognitive approaches. The Journal of Educational Research, 102(2), 137-151. https://doi.org/10.3200/JOER.102.2.137151

Laamena, C. M., \& Nusantara, T. (2019). Prospective mathematics teachers' argumentation structure when constructing a mathematical proof: The importance of backing. Beta: Jurnal Tadris Matematika, 12(1), 43-59.

Laamena, C. M., Nusantara, T., Irawan, E. B., \& Muksar, M. (2018). Analysis of the Students' argumentation based on the level of ability: Study on the process of mathematical proof. Journal of Physics: Conference Series, 1028(1), 012156. https://doi.org/10.1088/1742-6596/1028/1/012156

Laurens, T. (2010). Penjenjangan metakognisi siswa yang valid dan reliabilitas. Jurnal Pendidikan dan Pembelajaran (JPP), 17(2), 201-211.

Lingel, K., Lenhart, J., \& Schneider, W. (2019). Metacognition in mathematics: do different metacognitive monitoring measures make a difference?. ZDM, 51(4), 587-600. https://doi.org/10.1007/s11858-019-01062-8

Muhammad, N. B., Kumaidi, K., \& Mukminan, M. (2020). Factors of critical spatial thinking for a geography metacognition assessment in Indonesian Senior High Schools. Review of International Geographical Education Online, 10(2), 186-204. https://doi.org/10.33403/rigeo.686050

Novriani, M. R., \& Surya, E. (2017). Analysis of student difficulties in mathematics problem solving ability at MTs SWASTA IRA Medan. International Journal of Sciences: Basic and Applied Research (IJSBAR), 33(3), 63-75. 
Özenç, E. G., \& Dikici, H. (2016). The Correlation between the Fourth Grade Students' Level of Functional Literacy and Metacognitive Awareness. Journal of Education and Training Studies, 4(12), 108-117. https://doi.org/10.11114/jets.v4i12.1977

Prince, R. N., Frith, V., Steyn, S., \& Cliff, A. (2021). Academic and quantitative literacy in higher education: Relationship with cognate school-leaving subjects. South African Journal of Higher Education, 35(3), 163-181. https://doi.org/10.20853/35-3-3943

Reyes, J., Insorio, A. O., Ingreso, M. L. V., Hilario, F. F., \& Gutierrez, C. R. (2019). Conception and application of contextualization in mathematics education. International Journal of Educational Studies in Mathematics, 6(1), 1-18.

Root, J. R., Cox, S. K., Davis, K., \& Hammons, N. (2020). Contextualizing mathematical problem-solving instruction for secondary students with extensive support needs: A systematic replication. Research and Practice for Persons with Severe Disabilities, 45(4), 241-255. https://doi.org/10.1177/1540796920949448

Salam, M., Misu, L., Rahim, U., Hindaryatiningsih, N., \& Ghani, A. R. A. (2020). Strategies of Metacognition Based on Behavioural Learning to Improve Metacognition Awareness and Mathematics Ability of Students. International Journal of Instruction, 13(2), 61-72. https://doi.org/10.29333/iji.2020.1325a

Schneider, W., \& Artelt, C. (2010). Metacognition and mathematics education. ZDM, 42(2), 149-161. https://doi.org/10.1007/s11858-010-0240-2

Schoenfeld, A. H. (1987). What's all the fuss about metacognition?. In A. H. Schoenfeld (Ed.). Cognitive science and mathematics education (pp. 189-215). Hillsdale: Lawrence Erlbaum Associates.

Schoenfeld, A. H. (2016). Learning to think mathematically: Problem solving, metacognition, and sense making in mathematics (Reprint). Journal of Education, 196(2), 1-38. https://doi.org/10.1177/002205741619600202

Sholihah, S. Z., \& Afriansyah, E. A. (2017). Analisis kesulitan siswa dalam proses pemecahan masalah geometri berdasarkan tahapan berpikir Van Hiele. Mosharafa: Jurnal Pendidikan Matematika, 6(2), 287-298. https://doi.org/10.31980/mosharafa.v6i2.317

Smith, J. M., \& Mancy, R. (2018). Exploring the relationship between metacognitive and collaborative talk during group mathematical problem-solving-what do we mean by collaborative metacognition?. Research in Mathematics Education, 20(1), 14-36. https://doi.org/10.1080/14794802.2017.1410215

Stacey, K. (2011). The PISA View of Mathematical Literacy in Indonesia. Journal on Mathematics Education, 2(2), 95-126. https://doi.org/10.22342/jme.2.2.746.95-126

Stillman, G., \& Mevarech, Z. (2010). Metacognition research in mathematics education: from hot topic to mature field. ZDM, 42, 145-148. https://doi.org/10.1007/s11858010-0245-x

Su, H. F. H., Ricci, F. A., \& Mnatsakanian, M. (2016). Mathematical teaching strategies: Pathways to critical thinking and metacognition. International Journal of Research in Education and Science, 2(1), 190-200.

Sulistiyarini, A. (2021). School Literacy Movement (SLM) as a Solution to Increase Reading Interest of Indonesian Students. Ilkogretim Online, 20(1), 1324-1334. http://doi.org/10.17051/ilkonline.2021.01.127 
Tambychik, T., \& Meerah, T. S. M. (2010). Students' difficulties in mathematics problemsolving: What do they say? Procedia-Social and Behavioral Sciences, 8, 142-151. https://doi.org/10.1016/j.sbspro.2010.12.020

Veenman, M. V., \& van Cleef, D. (2019). Measuring metacognitive skills for mathematics: students' self-reports versus on-line assessment methods. ZDM, 51(4), 691-701. https://doi.org/10.1007/s11858-018-1006-5

Veenman, M. V., van Hout-Wolters, B. H., \& Afflerbach, P. (2006). Metacognition and learning: Conceptual and methodological considerations. Metacognition and learning, 1(1), 3-14. https://doi.org/10.1007/s11409-006-6893-0

Yee, S. P., \& Bostic, J. D. (2014). Developing a contextualization of students' mathematical problem solving. The Journal of Mathematical Behavior, 36, 1-19. https://doi.org/10.1016/j.jmathb.2014.08.002

Yong, H. T., \& Kiong, L. N. (2005). Metacognitive aspect of mathematics problem solving. In 3rd East Asia Regional Conference on Mathematics Education (ICMI Regional Conference).

Yong, S. T., Gates, P., \& Chan, A. T. Y. (2019). Similarities and differences in learning of metacognitive skills: Computer games versus mathematics education. International Journal of Game-Based Learning (IJGBL), 9(1), 1-14. https://doi.org/10.4018/IJGBL.2019010101

Zepeda, C. D., Hlutkowsky, C. O., Partika, A. C., \& Nokes-Malach, T. J. (2019). Identifying teachers' supports of metacognition through classroom talk and its relation to growth in conceptual learning. Journal of Educational Psychology, 111(3), 522-541. https://doi.org/10.1037/edu0000300

Zhong, B., \& Xia, L. (2020). A systematic review on exploring the potential of educational robotics in mathematics education. International Journal of Science and Mathematics Education, 18(1), 79-101. https://doi.org/10.1007/s10763-018-09939$\mathrm{y}$

Zhussupova, R., \& Kazbekova, M. (2016). Metacognitive strategies as points in teaching reading comprehension. Procedia-social and behavioral sciences, 228, 593-600. https://doi.org/10.1016/j.sbspro.2016.07.091 